\title{
Agminated atypical melanocytic nevus associated with Langerhans cell histiocytosis*
}

\author{
Ehekatzin Arturo Carreño-Gayosso ${ }^{1}$, Sarah Lizette Hernández-Peralta ${ }^{2}$, Elizabeth Guevara-Gutiérrez², \\ Guillermo Solís-Ledezma ${ }^{3}$
}

DOI: http:/ / dx.doi.org/10.1590/abd1806-4841.20198620

\begin{abstract}
Agminated nevus refers to the presence of multiple nevi grouped in a circumscribed skin area; it is rarely reported in the literature. This report presents the case of a 10-year-old female patient with a history of Langerhans cell histiocytosis, who presents multiple nevi in the lumbar and inguinal region. In the histopathological study, an atypical melanocytic nevus was reported. Wood's lamp examination discarded the presence of nevus spilus, and the diagnosis of agminated nevus was reached. The association of this type of nevus with Langerhans cell histiocytosis is rare, and only four cases were found reported in the indexed literature. The reason for this association is unknown, thus a new theory about its origin is presented here.
\end{abstract}

Keywords: Dysplastic nevus syndrome; Histiocytosis, Langerhans-cell; Nevus, pigmented

\section{INTRODUCTION}

The term "agminated nevus" is used to describe the presence of multiple nevi grouped on a circumscribed skin area. ${ }^{1}$ Langerhans cell histiocytosis ( $\mathrm{LCH})$ is a neoplasia derived from the dendritic cells with myeloid precursor. ${ }^{2}$ Agminated melanocytic nevus is rarely reported in the literature and only four cases associated to $\mathrm{LCH}$ were found, so it of great interest to report a clinical case with such association.

\section{CASE REPORT}

A 10-year-old female patient with a history of LCH diagnosed at 2 years of age and treated with chemotherapy with resolution of the disease. Her skin disease began at 4 years of age with the presence of "moles" in the left inguinal region and six months before the consultation in the lumbar region. Physical examination revealed more than 100 flat, pigmented, dark brown nevi, 1-2mm in diameter, grouped in an area of $6 \times 5 \mathrm{~cm}$ in diameter over the inguinal region on the left side, and 50 of them grouped in an area of $5 \times 4 \mathrm{~cm}$ in diameter located in the lumbar region (Figura 1 ). The dermoscopy proved typical reticular pattern, and in Wood's light the presence of nevus spilus was discarded (Figura 2). The histopathology report of one of the nevi showed a junctional melanocytic nevus with the presence of some cellular atypia, thus a diagnosis of agminated atypical melanocytic nevus associated with LCH was established (Figura 3).

\section{DISCUSSION}

The association of agminated nevi with $\mathrm{LCH}$ is extremely rare. The four cases reported in the literature presented were between ages of 2 to 11 years of age, but unlike the present case, all four were male. ${ }^{3-5}$ Another difference found is that two of them had common melanocytic nevi and the other two had Spitz and spitzoid nevi, while the present case is the first with atypical histological characteristics. However, all the reports agree that the lesions predominate in the skin folds, mainly in the inguinal region, a site that is also more frequently affected in LCH (Table 1$){ }^{6}$

Regarding pathogenesis, several theories have been proposed about the association between agminated nevus and $\mathrm{LCH}$. Surinach et al. ${ }^{4}$ propose that the origin of the nevus cells may be due to the fact that an increase in regulatory $\mathrm{T}$ lymphocytes has been observed in LCH lesions, leading to immunotolerance and to the Langerhans cells releasing proinflammatory cytokines that stimulate nevogenesis. These same authors have related the presence of the agminated nevus to the use of chemotherapy, which would be a triggering factor. However, the case reported by Feldstein et al. ${ }^{5}$

\footnotetext{
Received 15 July 2018.

Accepted 22 October 2018.

* Study conducted at the Instituto Dermatológico de Jalisco, Guadalajara, Jalisco, México.

Financial support: None.

Conflict of interest: None.

Dermatologic Surgery Department, Instituto Dermatológico de Jalisco, Guadalajara, Mexico.

Dermatology Department, Instituto Dermatológico de Jalisco, Guadalajara, Mexico.

Dermatopathology Department, Instituto Dermatológico de Jalisco, Guadalajara, Mexico.
}

MAILING AdDRESS:

Ehekatzin Arturo Carreño-Gayosso

E-mail: ehekatzin.dermamd@gmail.com

(C)2019 by Anais Brasileiros de Dermatologia 
was treated with topical corticosteroids, which makes this theory unlikely; in addition, it would not explain the higher prevalence of lesions in flexion zones or their appearance several years after having been exposed to antineoplastic drugs.

Therefore, a new theory is proposed here, which is based on the fact that up to two-thirds of cases of $\mathrm{LCH}$ present a somatic mutation in BRAFV600E, which causes an activation and over-expression of MAPK/ERK. This last is a kinase protein that is involved in the development, regulation, proliferation, differentiation, and cellular apoptosis. ${ }^{2,7}$ This mutation is considered the initial step in nevogenesis, and it is present in up to $78 \%$ of acquired melanocytic nevus and in $57.9 \%$ of atypical nevus. ${ }^{8}$ Therefore, the authors believe that the presence and over-expression of this mutation could give rise to multiple nevi in the sites of the skin affected by $\mathrm{LCH}$.

Regarding treatment, because the cases associated with $\mathrm{LCH}$ have had a benign behavior, treatment or removal of the ag-
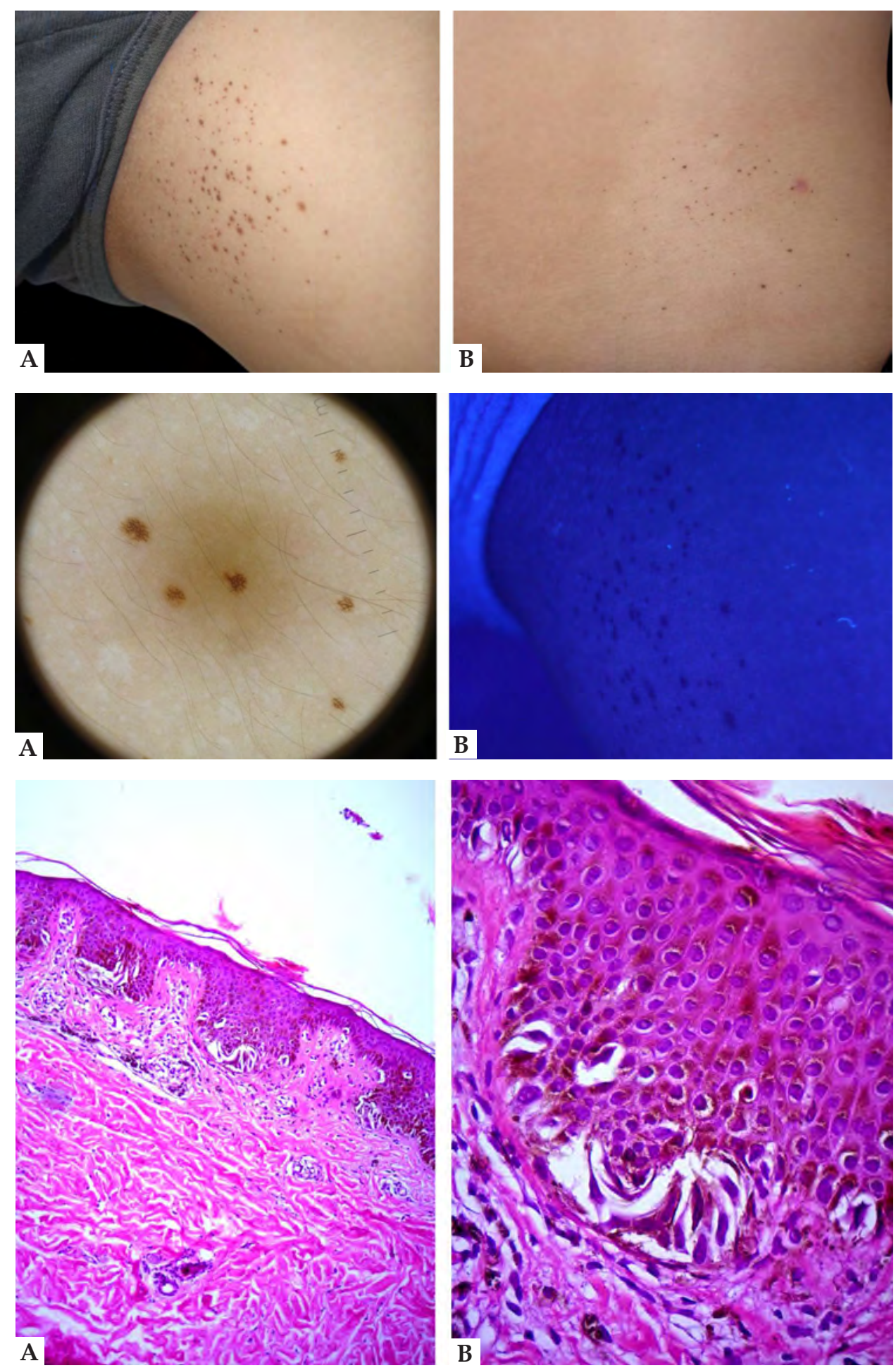

Figure 1: A - Multiple melanocytic nevi grouped in the inguinal region; B - Multiple melanocytic nevi grouped in the left lumbar region.

Figure 2: A - Typical reticular pattern in dermatoscopy; B - Wood's light showing no evidence of nevus spilus.

Figure 3: A - Basal collections of fusiform melanocytes, pigmented, and with notable nuclear atypia, papillary fibrosis, and lymphocytic infiltrate with melanophages (Hematoxylin \& eosin, x10); B - Close-up (Hematoxylin \& eosin, $x 40$ ). 
TABLE 1: Clinical characteristics of the cases with agminated nevus associated with Langerhans cell histiocytosis

\begin{tabular}{|c|c|c|c|c|c|}
\hline Features & Berk clos et al. ${ }^{4}$ & Surinach clos et al. ${ }^{5}$ & Surinach et al. ${ }^{5}$ & Feldstein et al. ${ }^{6}$ & This case \\
\hline $\begin{array}{l}\text { Age at diagnosis } \\
\text { (years) }\end{array}$ & 7 & 9 & 12 & 11 & 10 \\
\hline Gender & Male & Male & Male & Male & Female \\
\hline $\begin{array}{l}\text { Age at beginning } \\
\text { (years) }\end{array}$ & 5 & 2 & 11 & 8 & 4 \\
\hline Location & Inguinal bilaterally & $\begin{array}{l}\text { Inguinal bilaterally } \\
\text { and axillary }\end{array}$ & Inguinal bilaterally & $\begin{array}{l}\text { Inguinal bilaterally } \\
\text { axillary and } \\
\text { buttocks }\end{array}$ & $\begin{array}{l}\text { Inguinal and } \\
\text { lumbar }\end{array}$ \\
\hline Nevus number & $\begin{array}{c}>100 \\
1-2 \mathrm{~mm}\end{array}$ & $\begin{array}{l}>100 \\
1-4 \mathrm{~mm}\end{array}$ & $\begin{array}{c}>100 \\
\text { pinpoint }\end{array}$ & $\begin{array}{c}>100 \\
3-4 \mathrm{~mm}\end{array}$ & $\begin{array}{c}>100 \\
1-2 \mathrm{~mm}\end{array}$ \\
\hline Histology & $\begin{array}{c}\text { Junctional } \\
\text { epithelioid spitz } \\
\text { nevus }\end{array}$ & $\begin{array}{c}\text { Junctional nevus } \\
\text { with spitzoid } \\
\text { features }\end{array}$ & NS & $\begin{array}{c}\text { Junctional } \\
\text { melanocytic nevus }\end{array}$ & $\begin{array}{c}\text { Junctional } \\
\text { melanocytic nevus } \\
\text { with dysplastic } \\
\text { features }\end{array}$ \\
\hline Dermoscopy & NS & $\begin{array}{l}\text { Peripheral reticular } \\
\text { with central globules }\end{array}$ & Atypical network & NS & Diffuse reticular \\
\hline
\end{tabular}

NS, not specified.

minated nevus is not recommended..$^{3-5}$ However, there must be two considerations in this regard. First, cases of melanoma have been reported in patients with agminated melanocytic nevus, some of them with characteristics of atypical nevus syndrome., ${ }^{9,10}$ Second, although there have not been reported cases of melanoma in an agminated nevus associated with $\mathrm{LCH}$, it should be noted that these have had very short follow-ups, approximately two to seven years and the two cases related to melanoma had latency periods of 20 and 34 years, respectively, before the development of malignancy. ${ }^{3-5,9,10}$ Hence it is extremely important to closely monitor these patients from the clinical and dermatoscopic point of view, for assessment by biopsy or removal of suspicious lesions, on an ongoing basis. $\square$

\section{REFERENCES}

1. Monteagudo B, León A, García-Prieto W, Rodríguez-Blanco I, GarcíaRego JA, de las Heras $C$, et al. Nevos melanocíticos adquiridos agminados. Actas Dermosifiliogr. 2005;96:405-6.

2. El Demellawy D, Young JL, de Nanassy J, Chernetsova E, Nasr A. Langerhans cell histiocytosis: a comprehensive review. Pathology. 2015;47:294-301.

3. Berk DR, Lane AT. Acquired bilateral agminated Spitz nevi in a child with Langerhans cell histiocytosis. Pediatr Dermatol. 2010;27:282-4.

4. Surinach $C$, Bahadoran $P$, Vabres $P$, Chiaverini C, Montaudie H, Erfan $\mathrm{N}$, et al. Flexural agminated eruptive nevi in Langerhans cell histiocytosis. JAMA Dermatol. 2013;149:635-7.

5. Feldstein S, Funk T, Smith JC, Bruckner AL. Agminated flexural melanocytic nevi: a late sequela of Langerhans cell histiocytosis?. Pediatr Dermatol. 2015;32:e89-91.
6. Goodman WT, Barret T. Histiocytoses. In: Bolognia JL, Jorizzo JL, Schaffer JV, editors. Dermatology, China: Elsevier Saunders; 2012. p. 1529-35.

7. Monsereenusorn C, Rodriguez-Galindo C. Clinical characteristics and treatment of Langerhans cell histiocytosis. Hematol Oncol Clin North Am. 2015;29:853-73.

8. Roh MR, Eliades P, Gupta S, Tsao H. Genetics of melanocytic nevi. Pigment Cell Melanoma Res. 2015;28:661-72.

9. Corradin MT, Alaibac M, Fortina AB. A case of malignant melanoma arising from an acquired agminated melanocytic naevus. Acta Derm Venereol. 2007;87:432-3.

10. Rezze GG, Leon A, Silva DC, Neves RI, Molina GC, Carraro DM, et al. Primary cutaneous melanoma arising in agminated melanocytic nevi: CDKN2A and CDK4 mutation screening. Acta Derm Venereol. 2012:92:98-9.

\footnotetext{
AUTHORS' CONTRIBUTIONS

Ehekatzin Arturo Carreño-Gayosso

iD ORCID

0000-0002-5532-0576

Statistical analysis; approval of the final version of the manuscript; study design and planning; manuscript preparation and writing; data collection, analysis and interpretation; effective participation as research advisor; intellectual participation in propaedeutic and/or therapeutic conduct of studied cases; critical literature review; critical manuscript review.

Sarah Lizette Hernández-Peralta

ORCID 0000-0002-6354-9784

Statistical analysis; approval of the final version of the manuscript; study design and planning; data collection, analysis and interpretation; effective participation as research advisor; intellectual participation in propaedeutic and/or therapeutic conduct of studied cases; critical literature review; critical manuscript review.

Elizabeth Guevara-Gutiérrez $\quad$ (iD) ORCID 0000-0002-2911-1957

Statistical analysis; approval of the final version of the manuscript; manuscript preparation and writing; data collection, analysis and interpretation; critical literature review; critical manuscript review.

Guillermo Solís-Ledezma $\quad$ (iD) ORCID 0000-0003-2108-0487

Statistical analysis; approval of the final version of the manuscript; data collection, analysis and interpretation; effective participation as research advisor; critical manuscript review.
}

How to cite this article: Carreño-Gayosso EA, Hernández-Peralta SL, Guevara-Gutiérrez E, Solís-Ledezma G. Agminated atypical melanocytic nevus associated with Langerhans cell histiocytosis. An Bras Dermatol. 2019;94(4):455-7. 